\title{
Seasonal patterns of light availability and light use of broadleaf evergreens in a deciduous forest understory: Potential mechanisms for expansion
}

\author{
Sheri A. Shiflett ${ }^{1}$, Julie C. Zinnert ${ }^{1,2}$, Donald R. Young ${ }^{1^{*}}$ \\ ${ }^{1}$ Department of Biology, Virginia Commonwealth University, Richmond, USA; ${ }^{*}$ Corresponding Author: dryoung@,vcu.edu \\ ${ }^{2}$ US Army ERDC, Fluorescence Spectroscopy Lab, Alexandria, USA
}

Received 30 January 2013; revised 1 March 2013; accepted 31 March 2013

Copyright (C) 2013 Sheri A. Shiflett et al. This is an open access article distributed under the Creative Commons Attribution License, which permits unrestricted use, distribution, and reproduction in any medium, provided the original work is properly cited.

\section{ABSTRACT}

In recent years, expansion of native and exotic evergreen shrubs into forest understories has been documented worldwide. Dense shrub thickets may interfere with tree establishment, suppress herbaceous cover, and contribute substantially to total standing crop of leaf biomass. Expansion may occur because evergreen shrubs exploit seasonal variations in irradiance and temperature that are characteristic of temperate understory environments. We quantified leaf-level light environment and photosynthetic activity of three sympatric broadleaf evergreens (llex opaca, Kalmia latifolia, and Myrica cerifera) in a deciduous forest understory in Charles City County, Virginia, USA in order to understand seasonal intra- and interspecific ranges of broadleaf evergreen physiology. Two species $(K$. latifolia and $M$. cerifera) represent a diverse taxonomic range within broadleaf evergreens, and often form expansive thickets. We measured parameters related to canopy structure (e.g., bifurcation ratio, leaf angle) and photosynthetic performance (e.g., electron transport rate or ETR, chlorophyll content), to identify potential mechanisms facilitating expansion. ETR varied both seasonally and among species. In summer, $M$. cerifera ETR was nearly double that of $I$. opaca or K. latifolia. Additionally, leaf temperature enhanced photosynthetic capacity of expansive species. Evergreen species, though capable of fixing carbon throughout the year, often exhibit slow growth rates and low physiological activity. Yet, we observed that the range of evergreen physiological activity may be broader than previously recognized. Furthermore, our results indicate potential for changes in composition and expansion of the evergreen shrub layer by species that exhibit structural and physiological mechanisms advantageous for future rises in temperature.

Keywords: Chlorophyll Fluorescence; Evergreenness; Temperate Forest; Photosynthetic Capacity; Seasonal Irradiance

\section{INTRODUCTION}

Expansion of evergreen shrubs, both native and exotic, (e.g., Ligustrum robustum, Ligustrum sinense, Myrica faya, Rosa multiflora) into forest understories worldwide has been documented [1-5]. Dense shrub thickets may interfere with tree establishment, suppress herbaceous cover, and contribute a substantial amount to total standing crop of leaf biomass [6,7]. Over the past several decades, expansion of the evergreen understory layer of deciduous forests has also been documented [8]. Within the Southern Appalachian Mountains of North America, 2.5 million ha are covered by thickets of Kalmia latifolia and Rhodedendron maximum [6,9]. Recently Myrica cerifera, a nitrogen-fixing, evergreen shrub, which occurs in open environments and forest understories, has also received attention for forming dense, monospecific thickets that encroach into nearby communities [10-12]. Species that form dense thickets may provide insight for understanding what suites of characteristics and physiological responses lead to occurrence and expansion within the understory.

Species that display the evergreen leaf habit may remain active throughout the year and invest less annually in carbon and nutrients necessary to maintain foliage [6, 13-15].This leads to longer leaf life spans than deciduous species, but lower rates of photosynthesis [15-18], 
growth, nutrient loss, and litter decomposition $[6,13,14]$. Evergreen trees and shrubs are favored in nutrient poor environments because the consequences of lower photosynthetic capacity can be mitigated by assimilating carbon over a longer growing season [19-21]. Typical growth characteristics of evergreens are linked to low responsiveness to environmental change and consequently, climate change may lead to shifts in evergreen distribution [15].

In temperate climates, broadleaved evergreen species in the deciduous forest understory are exposed to large fluctuations in irradiance and temperature throughout the year [22-24]. The light environment in the forest understory is highly dynamic and photosynthetically active radiation (PAR) reaching leaves may increase or decrease over two orders of magnitude within seconds [25-27]. Large changes in PAR occur in the understory due to leaf-out in the spring and autumn canopy leaf fall. Understory leaf temperature exhibits large fluctuations due to seasonality, and intensity and duration of irradiance $[22,24]$. Some understory evergreens, such as Ilex opaca, are dependent on the relatively high irradiance when the overstory is leafless $[28,29]$. Though previous studies quantified variations in understory light, few studies have examined seasonal physiology of understory woody plants.

The objective of our study was to characterize and compare leaf-level light environment and photosynthetic capacity among broadleaf evergreen species to identify mechanisms related to expansion. We investigated the response of evergreen understory woody species to seasonal differences in light environment and temperature by 1) quantifying seasonal variations in leaf pigments, as related to light availability, 2) identifying structural traits associated with light capture (e.g., branch bifurcation, leaf angle) and that were related to photosynthetic capacity, 3) comparing photosynthetic capacity across seasons, and 4) determining if expansive, thicket-forming species
(K. latifolia and M. cerifera) display physiology reflective of expansive potential in the understory. We hypothesized that species would display traits enabling maximum light capture due to a heterogeneous seasonal light environment and that species considered as expansive in some environments would display higher photosynthetic capacity than the non-expansive $I$. opaca throughout the growing season.

\section{MATERIALS AND METHODS}

\subsection{Site Description}

Field work was conducted at the Inger and Walter Rice Center for Environmental Studies, located in Charles City County, VA $\left(37^{\circ} 19^{\prime} \mathrm{N}, 77^{\circ} 12^{\prime} \mathrm{W}\right)$, from March 2010 to November 2011. Species were sampled within a mature (80 - 150 years old) hardwood forest understory. The deciduous forest canopy was primarily composed of a mixture of Quercus spp., and Acer rubrum. Physiological measurements were conducted from March 2010 to November 2011 on Ilex opaca Aiton (Aquifoliaceae), Kalmia latifolia L. (Ericaceae), and Myrica cerifera L. (Myricaceae), broadleaf evergreen species of varying leaf longevity which represent a wide geographic range in eastern North America (Table 1).

Ilex opaca, which grows in either the tree or shrub growth form, is frequently observed in forest under stories as a small tree $\sim 10 \mathrm{~m}$ tall. Kalmia latifolia, which typically occurs on forested slopes, can grow between 3 $9 \mathrm{~m}$ tall and is capable of forming dense thickets. Myrica cerifera, also capable of forming dense thickets, fixes nitrogen symbiotically, can reach heights of $5-6 \mathrm{~m}$, and typically occurs in the southern United States.

\subsection{Measurements}

Early spring, late spring, summer and autumn measurements were performed in March, May, July and

Table 1. General life history, physiology, and habitat characteristics of study species: I. opaca, K. latifolia, and M. cerifera. Maximum photosynthetic rates have not been published for $I$. opaca and therefore, values presented are from closely related Ilex aquifolium, which is typically observed in European oak and beech forests.

\begin{tabular}{|c|c|c|c|c|c|}
\hline Species & N-Fixer & $\begin{array}{l}\text { Leaf life } \\
\text { span (yrs) }\end{array}$ & $\begin{array}{l}\text { Maximum } \\
\text { photosynthetic rate } \\
\left(\mu \mathrm{mol} \cdot \mathrm{m}^{-2} \cdot \mathrm{sec}^{-1}\right)\end{array}$ & Preferred habitat & Distribution \\
\hline I. opaca & $\mathrm{N}$ & $\sim 2.4^{\mathrm{a}}$ & $\begin{array}{c}4-5^{\mathrm{b}} \\
\text { Ilex aquifolium }\end{array}$ & $\begin{array}{l}\text { an understory tree, but may grow in } \\
\text { full sun: grows best in mesic, } \\
\text { well-drained, slightly acidic soils }\end{array}$ & $\begin{array}{l}\text { native to eastern and southeastern United } \\
\text { States from coastal Massachusetts south to } \\
\text { central Florida, and west to southeastern } \\
\text { Missouri and eastern Texas }\end{array}$ \\
\hline K. latifolia & $\mathrm{N}$ & $\sim 3^{\mathrm{c}}$ & $4-8^{d}$ & $\begin{array}{c}\text { an understory shrub, but may grow in } \\
\text { full sun: grows best in mesic, } \\
\text { well-drained, acidic soils }\end{array}$ & $\begin{array}{l}\text { native to eastern United States, occurring } \\
\text { from southern Maine south to northern } \\
\text { Florida, and west to Indiana and Louisiana }\end{array}$ \\
\hline M. cerifera & $\mathrm{Y}$ & $<1^{\mathrm{e}}$ & $24-28^{f}$ & $\begin{array}{l}\text { frequently occurs in open areas, but } \\
\text { also along forest edges and in } \\
\text { understories: grows best in mesic soils }\end{array}$ & $\begin{array}{c}\text { native to eastern and southeastern United } \\
\text { States from coastal New Jersey south to } \\
\text { central Florida, and west to Texas }\end{array}$ \\
\hline
\end{tabular}

${ }^{\mathrm{a}}[30],{ }^{\mathrm{b}}[31],{ }^{\mathrm{c}}[32],{ }^{\mathrm{d}}[33],{ }^{\mathrm{e}, \mathrm{f}}[34]$. 
September, respectively. For each species, leaf angle to the horizontal $(\theta, n=100)$ was quantified to the nearest $5^{\circ}$ using a clinometer. Leaf angle was measured in early spring and again in summer to track seasonal changes. Plant bifurcation ratios were measured for ten stems exhibiting terminal shoots exposed to partial to full sunlight. The following equation was used to approximate branch bifurcation ratio $\left(R_{b}\right)$ :

$$
R_{b}=\frac{N-1}{N-N_{1}}
$$

where $N$ is the total number of branches of all branch orders on the stem and $N_{1}$ is the total number of first order branches [35]. Additionally, the number of leaves per primary branch was quantified and leaf area $(n=25)$ was measured using an area meter (LI-3100C). In order to assess leaf pigments, chlorophyll concentrations were quantified using standard spectrophotometric methods following acetone extraction [36].

Chlorophyll fluorescence analysis, including quantification of electron transport rate (ETR), is an increasingly popular alternative to gas exchange measurements for determination of photosynthetic performance of plants [37] and making comparisons among species [38]. Changes in fluorescence emissions correlate with the light use efficiency of $\mathrm{O}_{2}$ evolution $[39,40]$ and $\mathrm{CO}_{2}$ assimilation [41-43]. Further, maximum apparent ETR represents a measure for the capacity of photosynthetic activity $[44,45]$. We utilized chlorophyll fluorescence analysis in order to relate physiology to photosynthetic capacity $[45,46]$.

Measurements were collected on sunny days between $1000 \mathrm{~h}$ and $1400 \mathrm{~h}$. To estimate photosynthetic capacity, light-adapted leaf photosynthetic electron transport rate (ETR) was measured on fully expanded leaves $(n=50)$ using a pulse amplitude modulated leaf fluorometer (PAM-2000, Walz, Effeltrich, Germany). Leaves were selected from partially sunlit plants to capture natural variation in incident light and to ensure that some samples were acclimated to full sun. Concomitant incident photosynthetically active radiation (PAR) and leaf temperature were determined using the mini-PAM leaf clip (2030-B) quantum sensor and thermocouple. Apparent ETR was calculated as:

$$
E T R=\Delta F / F_{m}^{\prime} \times P A R \times 0.84 \times 0.5
$$

where $\Delta F / F_{m}^{\prime}$ represents quantum yield, 0.84 is the assumed light absorbance of the sample, and 0.5 corrects for 2 quanta of light required for the transport of 1 electron $[41,44]$.

\subsection{Data Analysis}

The program $\mathrm{R}$ was used for all statistical tests. Oneway analysis of variance (ANOVA) was conducted to compare leaf angles, leaf PAR, parameters relating to leaf pigments and ETR among species. Post-hoc testing was performed using Tukey's honestly significant difference (HSD). Linear regression analysis was used to determine relationships between PAR and leaf temperature for each species and significance of slopes was determined. The slopes of significant relationships were compared using a Student's t-test. Linear regression was also used to quantify relationships between PAR and ETR for determination of photosynthetic efficiency (PE) among species [47]. This was achieved by utilizing the linear portion of the relationship between PAR and ETR, which corresponded to PAR values $\leq 600 \mu \mathrm{mol} \cdot \mathrm{m}^{-2} \cdot \mathrm{sec}^{-1}$ and resulting ETR. Steeper slope in the linear portion of the relationship indicates higher PE (i.e., higher capacity for light processing). Slopes were compared to each other using analysis of covariance methods (ANCOVA) and when appropriate, pairwise contrasts were performed.

\section{RESULTS}

\subsection{Canopy Architecture and Leaf Anatomy}

Frequency distributions of $\theta$ among species in early spring were all different from one another (Figure $\left.\mathbf{1} ; F_{2,297}=37.87, P<0.001\right)$. Within species, frequency distributions of $\theta$ were similar between early spring and summer for $I$. opaca and $M$. cerifera ( $P=0.41,0.18$, respectively) and differed for $K$. latifolia $(P<0.001)$. In early spring for both $I$. opaca and $M$. cerifera, the largest proportion of leaves was angled horizontally between $0^{\circ}-15^{\circ}$. The largest proportion of leaves of $K$. latifolia displayed a $30^{\circ}-45^{\circ}$ leaf angle. Frequency distributions $\theta$ in summer varied among species $\left(F_{2,297}=\right.$ 10.26, $P<0.001$; Figure 1). Leaf angle distribution of $I$. opaca differed from both $K$. latifolia and $M$. cerifera $(P$ $=0.016<0.001$, respectively). In summer the largest proportion of leaves for all species occurred between 0 $15^{\circ}$, though a similarly large proportion of leaves of $M$. cerifera occurred between $15^{\circ}-30^{\circ}$ (Figure 1).

Bifurcation ratios $\left(R_{b}\right)$ were also significantly different among species $\left(F_{2,27}=4.31, P=0.02\right.$; Table 2$)$. Mean $R_{b}$ of $M$. cerifera was approximately one and a half times the value of $I$. opaca or $K$. latifolia, but values were not significantly different between $I$. opaca and $M$. cerifera. Leaf area differed among species $\left(F_{2,72}=63.0, \mathrm{P}\right.$ $<0.001)$ such that leaves of $M$. cerifera were smaller than leaves of I. opaca or K. latifolia (Table 2). Myrica cerifera also produced nearly twice as many leaves per primary branch as I. opaca or K. latifolia $\left(F_{2,12}=16.31\right.$, $\mathrm{P}<0.001)$. Yet, when expressed as leaf area per primary branch, I. opaca produced the most $\left(151 \pm 0.4 \mathrm{~cm}^{2}\right)$, followed by $K$. latifolia $\left(121 \pm 0.4 \mathrm{~cm}^{2}\right)$, and $M$. cerifera $\left(100 \pm 0.8 \mathrm{~cm}^{2}\right)$. 


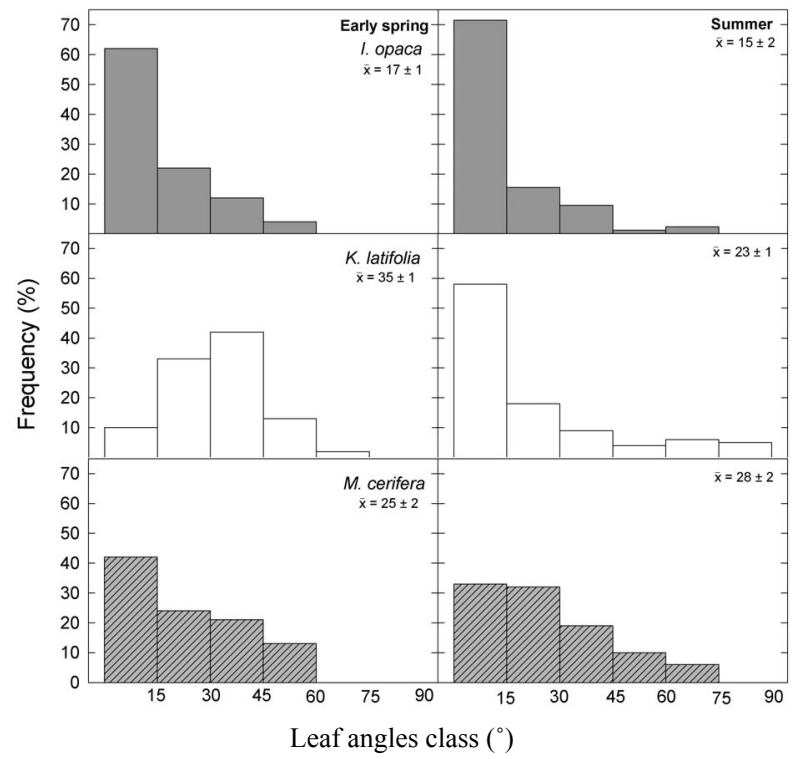

Figure 1. Frequency distributions of leaf angles relative to horizontal of I. opaca, K. latifolia, and M. cerifera during early spring and summer. Distributions are divided into $15^{\circ}$ classes. Mean leaf angle \pm 1 standard errors (SE) are presented for each species during a given season.

Table 2. Anatomical and structural characteristics of $I$. opaca, $K$. latifolia, and M. cerifera. Significant differences $(\mathrm{P}<0.05)$ among species for a given characteristic are represented by letters.Mean values are presented with \pm one standard error (SE).

\begin{tabular}{ccccc}
\hline Characteristic & $\mathrm{N}$ & I. opaca & K. latifolia & M. cerifera \\
\hline $\begin{array}{c}\text { Leaf area }\left(\mathrm{cm}^{2}\right) \\
\text { No. of leaves per }\end{array}$ & 15 & $16.7 \pm 0.7^{\mathrm{a}}$ & $15.7 \pm 0.9^{\mathrm{a}}$ & $6.5 \pm 0.5^{\mathrm{b}}$ \\
$\begin{array}{c}1^{\circ} \text { branch } \\
\text { Bifurcation ratio }\end{array}$ & 10 & $2.6 \pm 0.6^{\mathrm{a}}$ & $7.7 \pm 0.4^{\mathrm{a}}$ & $15.3 \pm 1.6^{\mathrm{b}}$ \\
\hline
\end{tabular}

Chlorophyll $a: b$ ratios varied among species during early spring $\left(F_{2,27}=12.8, P<0.001\right)$ and summer $\left(F_{2,27}\right.$ $=12.2, P<0.001$; Figure 2). Ilex opaca had the largest chlorophyll $a: b$ ratio, while there were no significant differences between $K$. latifolia and M. cerifera. All species showed significantly reduced chlorophyll $a: b$ ratios in late spring and autumn compared to early spring and summer (Figure 2). Carotenoid content was highest in all species during early spring and summer (Figure 2). Carotenoid content of $I$. opaca was significantly lower than $K$. latifolia and $M$. cerifera during all seasons, and was similar between $K$. latifolia and M. cerifera.

\subsection{Light Environment}

Significant variation in incident leaf PAR on frequency distributions among species occurred in both early spring $\left(F_{2,148}=3.67, P=0.028\right)$ and summer

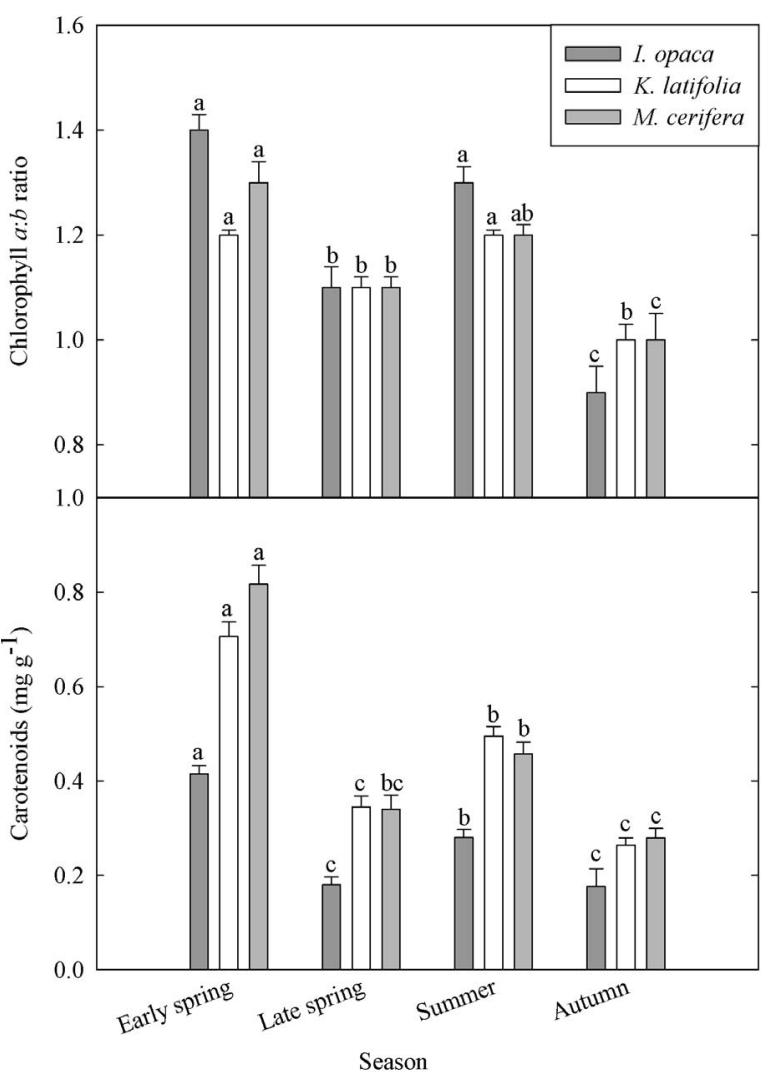

Figure 2. Seasonal chlorophyll $a: b$ ratio and carotenoid content $\left(\mathrm{mg} \cdot \mathrm{g}^{-1}\right)$ of I. opaca, K. latifolia, and $M$. cerifera. Intraspecific seasonal significant differences $(P<0.05)$ are represented by letters. Error bars represent $\pm 1 \mathrm{SE}$ of the mean.

$\left(F_{2,147}=7.01, P<0.001\right.$; Figure 3$)$. In early spring the distribution of leaf PAR was significantly lower in $M$. cerifera compared to $K$. latifolia, yet the leaf PAR of $I$. opaca did not differ from the other two species. In summer leaf PAR of I. opaca was significantly lower than $K$. latifolia, yet the leaf PAR of each was similar to $M$. cerifera. Throughout the growing season, leaves of each species were exposed to PAR ranging from $<25 \mu \mathrm{mol}$ $\mathrm{m}^{-2} \cdot \mathrm{sec}^{-1}$ to $\geq 1600 \mu \mathrm{mol} \cdot \mathrm{m}^{-2} \cdot \mathrm{sec}^{-1}$.

\subsection{Electron Transport Rate}

ETR varied both among species and seasonally (Figure 4). Throughout the growing season, both ETR and $\mathrm{PE}$ were similar for I. opaca and K. latifolia; yet, during all seasons except early spring, PE of $M$. cerifera was significantly higher than I. opaca and K. latifolia (Table 3). During most of the growing season, the slope of PAR and ETR for M. cerifera was steeper than that of I. opaca or $K$. latifolia (Table 3). To further investigate this relationship, light levels were classified as "low," "intermediate," and "high" intensities. "Low" intensity was considered light values ranging from $0-400 \mu \mathrm{mol} \cdot \mathrm{m}^{-2} \cdot \mathrm{sec}^{-1}$, "intermediate" intensity was values ranging from $600-$ 


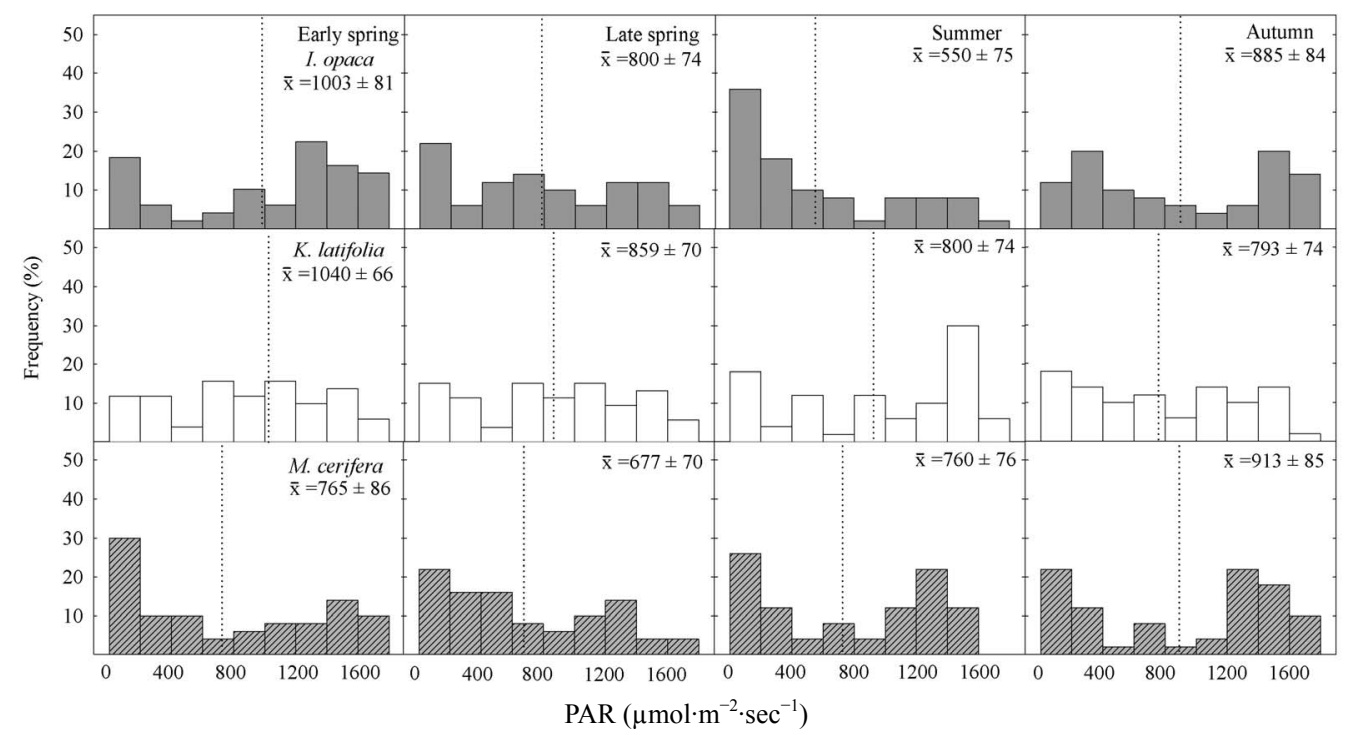

Figure 3. Seasonal frequency distributions of leaf photosynthetically active radiation (PAR $\mu \mathrm{mol} \cdot \mathrm{m}^{-2} \cdot \mathrm{sec}^{-1}$ ), obtained from the mini-PAM quantum sensor, for I. opaca, K. latifolia, and M. cerifera. Mean PAR $\pm 1 \mathrm{SE}$ are presented for each species during a given season and mean values are represented by dotted lines.

Table 3. Slopes of seasonal relationships between incident photosynthetically active radiation (PAR) $\leq 600 \mu \mathrm{mol} \cdot \mathrm{m}^{-2} \cdot \mathrm{sec}^{-1}$ and electron transport rate (ETR) for I. opaca (I), K. latifolia (K), and M. cerifera (M). Higher slopes correspond to greater photosynthetic efficiency (PE). ANCOVA model significance and $P$-values for pairwise contrasts are presented. ES = early spring; $\mathrm{LS}=$ late spring; $\mathrm{S}=$ summer; and $\mathrm{A}=$ autumn.

\begin{tabular}{ccccccccc}
\hline & \multicolumn{3}{c}{ Slope } & \multicolumn{2}{c}{ Model Significance } & \multicolumn{3}{c}{ Contrasts } \\
\hline Season & I & K & M & $F$ & $P$ & I vs K & I vs M & K vs M \\
\hline ES & 0.07 & 0.06 & 0.09 & 36.44 & $<0.0001$ & 0.21 & 0.52 & 0.40 \\
LS & 0.11 & 0.12 & 0.21 & 97.27 & $<0.0001$ & 0.93 & $<0.0001$ & 0.0002 \\
S & 0.08 & 0.10 & 0.19 & 30.23 & $<0.0001$ & 0.66 & 0.0002 & 0.005 \\
A & 0.06 & 0.09 & 0.23 & 33.76 & $<0.0001$ & 0.68 & $<0.0001$ & $<0.0001$ \\
\hline
\end{tabular}

$1000 \mu \mathrm{mol} \cdot \mathrm{m}^{-2} \cdot \mathrm{sec}^{-1}$ and "high" intensity was values ranging from $1200-1600 \mu \mathrm{mol} \cdot \mathrm{m}^{-2} \cdot \mathrm{sec}^{-1}$. The only difference between ETR of I. opaca and K. latifolia was observed at high light during autumn $(P<0.001)$. From late spring to autumn, ETR of $M$. cerifera was greater than I. opaca and $K$. latifolia at all light levels $(P<0.05$ in low light, and $P<0.005$ in intermediate and high light during this time period), with the largest differences occurring at intermediate and high light levels. Among species, highest observed ETR occurred for M. cerifera during summer.

At all light levels, ETR of $M$. cerifera increased with increasing leaf temperature (e.g., $r^{2}=0.85$ at low light, $r^{2}=0.89$ at intermediate light and $r^{2}=0.99$ in high light, $P<0.01$ in all cases; Figure 5). At high light, ETR of $K$. latifolia also increased linearly with increasing leaf temperature $\left(r^{2}=0.69\right.$; Figure 5). At low and intermediate light levels, no significant relationship existed between leaf temperature and ETR for K. latifolia
( $r^{2}=0.27, P=0.29$ and $r^{2}=0.34, P=0.23$, respectively, data not shown). No relationship existed between temperature and ETR for I. opaca at all light levels ( $r^{2} \leq 0.5$ and $P>0.1$ in all cases, data not shown). Additionally, the slope of the relationship between temperature and ETR was substantially steeper for $M$. cerifera than I. opaca or K. latifolia ( $P<0.001$; Figure 5).

\section{DISCUSSION}

Evergreen species are often noted for the ability to fix carbon throughout the year at the expense of low physiological activity and slow growth rates $[9,13,16,19]$. Yet, the range of physiological activity that broad-leaved evergreens display may be more extensive than previously recognized. We quantified a wide range of responses in parameters related to light capture and photosynthetic potential in understory evergreens in a deciduous forest demonstrating that there are several strategies for sur- vival in the understory among broadleaf ever 


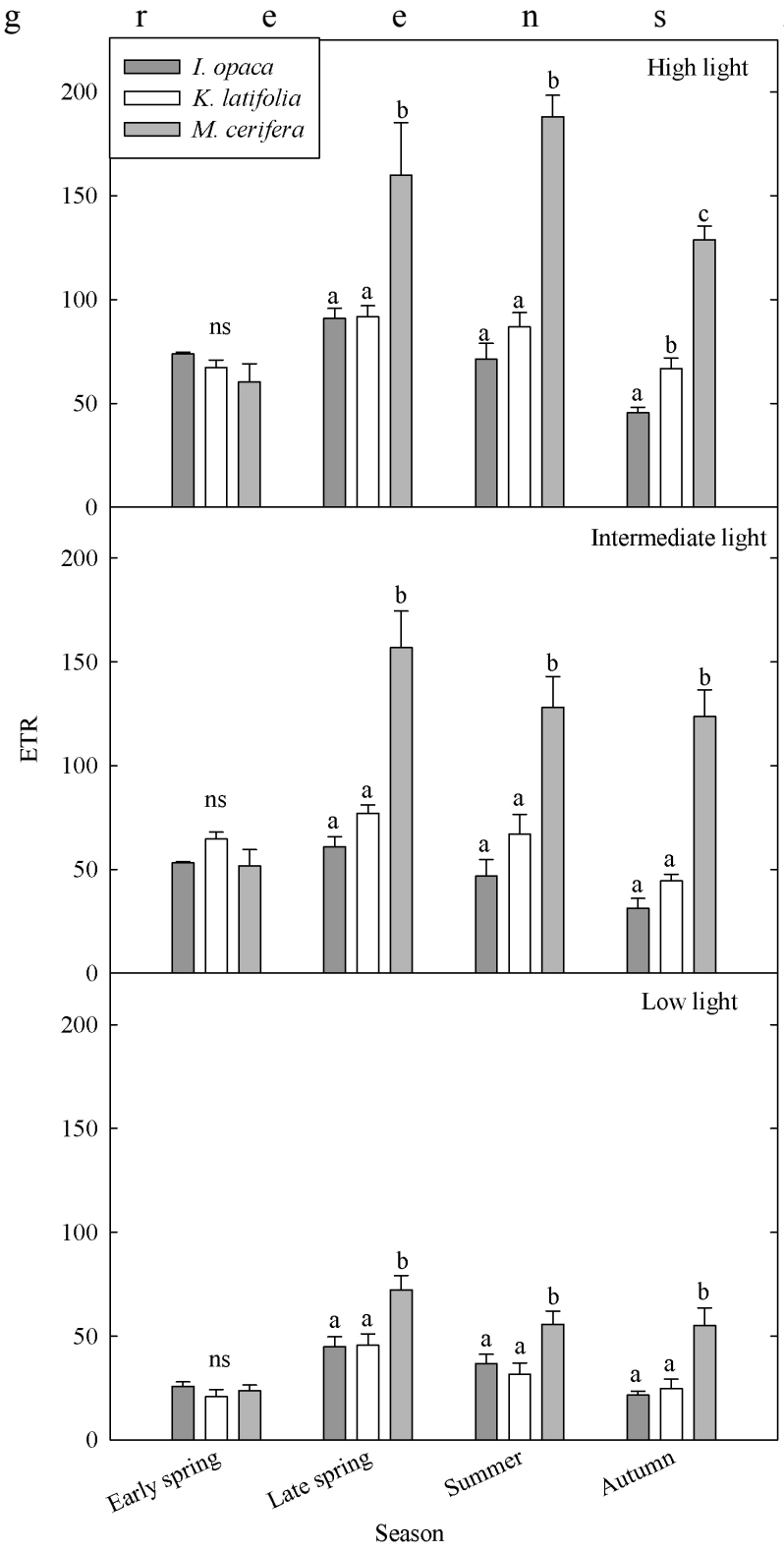

Figure 4. Seasonal ETR of three evergreen understory shrub species at low $\left(0-400 \mu \mathrm{mol} \cdot \mathrm{m}^{-2} \cdot \mathrm{sec}^{-1}\right)$, intermediate $(600$ $\left.1000 \mu \mathrm{mol} \cdot \mathrm{m}^{-2} \cdot \mathrm{sec}^{-1}\right)$, and high $\left(1200-1600 \mu \mathrm{mol} \cdot \mathrm{m}^{-2} \cdot \mathrm{sec}^{-1}\right)$ light intensities. Significant differences $(P<0.05)$ among species during a given month are represented by letters. A notation of ns indicates no significant differences were observed. Error bars represent $\pm 1 \mathrm{SE}$ of the mean.

Plant traits associated with light capture were not necessarily related to photosynthetic capacity, but all species showed traits aimed at maximizing light capture rather than light avoidance. Seasonal variations in leaf chlorophyll $a: b$ ratios and accessory pigments mirrored changes in light availability. Photosynthetic performance varied substantially throughout the growing season both intraand interspecifically. In addition, physiology of thicketforming species (K. latifolia and M. cerifera) reflected potential for expansion in the understory.

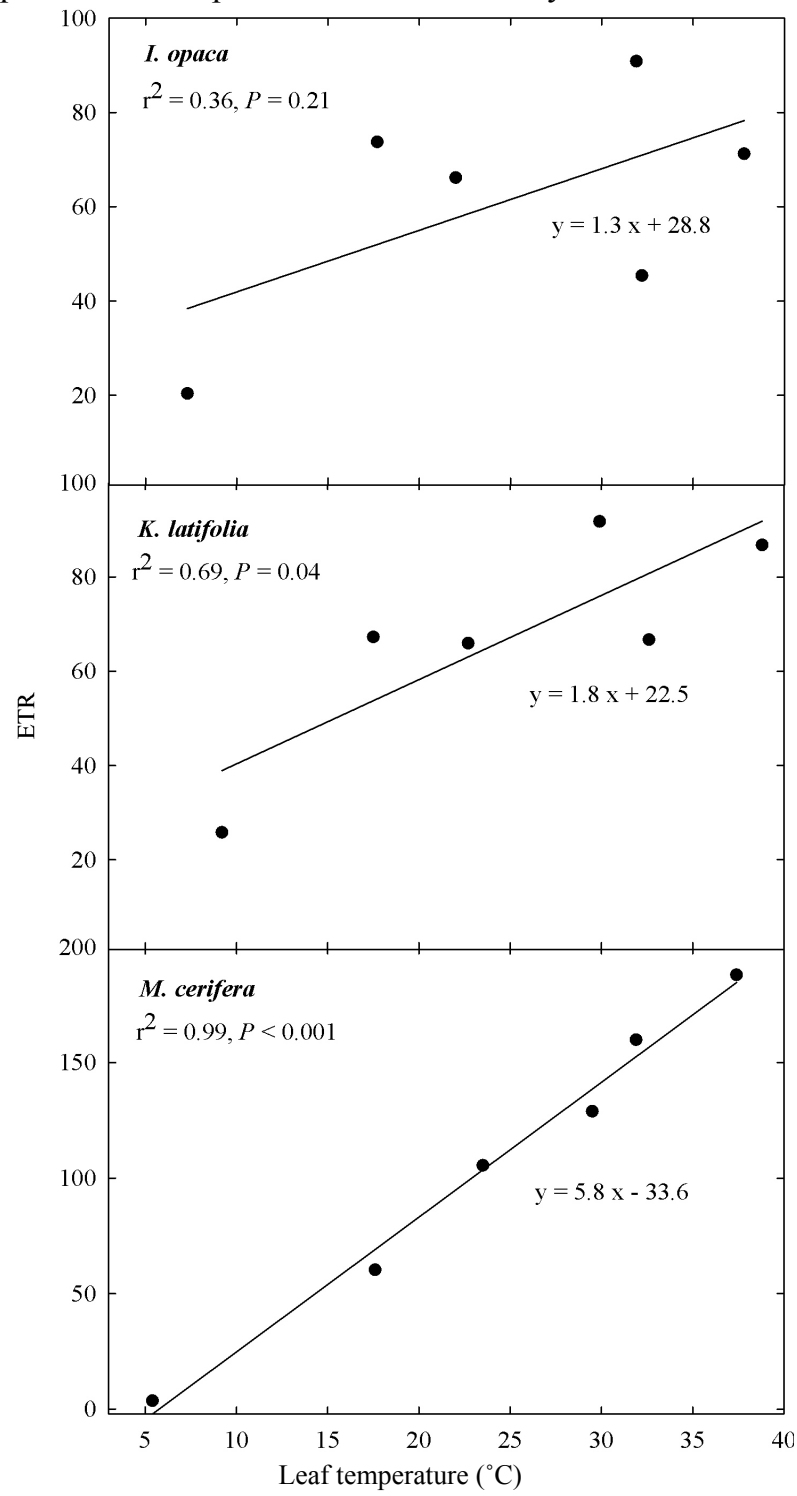

Figure 5. Relationship between leaf temperature $\left({ }^{\circ} \mathrm{C}\right)$, obtained from the mini-PAM during seasonal leaf chlorophyll fluorescence readings, and ETR at "high" light (i.e., PAR ranging from $1200-1600 \mu \mathrm{mol} \cdot \mathrm{m}^{-2} \cdot \mathrm{sec}^{-1}$ ) for I. opaca, K. latifolia, and M. cerifera.

Maximizing light capture through horizontal leaf orientation [48] was evident in all three species. Self-shading may be prevented at the leaf level by effective foliage orientation, a mechanism which enhances daily wholecanopy radiation capture through optimal light intercepttion earlier and later in the day when radiation is reduced [49-51]. The difference in leaf angle of $K$. latifolia between early spring and summer corresponded to closure of the overstory canopy; more leaves were oriented horizontally. In summer, the majority of leaves were closer to the horizontal plane, suggesting maximimum light capture for all three species. Instantaneous meas- 
urements of incident PAR showed that during any given season, leaves of each species were exposed to PAR values ranging from full shade $\left(<25 \mu \mathrm{mol} \cdot \mathrm{m}^{-2} \cdot \mathrm{sec}^{-1}\right)$ to nearly full sun $\left(\geq 1600 \mu \mathrm{mol} \cdot \mathrm{m}^{-2} \cdot \mathrm{sec}^{-1}\right)$, which also emphasizes the importance of foliage orientation for optimal light interception.

Canopy structure is a key factor influencing light interception by a forest stand with a given leaf area index (LAI) [52] and may influence branching strategies that optimize light capture [53-55]. Trees and shrubs growing in low light tend to exhibit lower bifurcation ratios and are associated with a nonrandom monolayer canopy, as compared to those exposed to high light and within a multilayered canopy $[53,56]$. Bifurcation ratio was highest for $M$. cerifera, yet similar to other values reported for forest understories [29,35,54]. Myrica cerifera also produced the most and smallest leaves per primary branch, minimizing self-shading [35]. Coupling these traits with consistent seasonal horizontal leaf angles suggests that $M$. cerifera displays architecture that promotes maximum light capture more so than I. opaca or $K$. latifolia.

Changes in carotenoids, which contribute to either light collection or photoprotection [57], tracked seasonal light availability. All species showed increased carotenoids when seasonal light availability was highest in early spring. Chlorophyll $a: b$ ratio, which increases with available light [58-60], also mirrored patterns in seasonal light availability. Interestingly, instantaneous leaf-level light did not vary at midday throughout the seasons for $K$. latifolia and $M$. cerifera, though it was lower in late spring and summer than early spring or autumn for $I$. opaca. Leaf pigments such as carotenoids and chlorophyll $a: b$ ratios provide metrics for understanding light availability that integrates seasonal variation.

Photosynthetic capacity varied substantially throughout the seasons for all species. ETRs observed during our study were proportional to previously reported photosynthetic rates for these, or closely related, species (Table 1). Most striking were the increases in ETR from late spring to autumn for $M$. cerifera. In cooler months, ETR of $M$. cerifera was the same as I. opaca and K. latifolia, but from late spring to early fall, ETR of $M$. cerifera was more than double that of the sympatric evergreen species. An increase in leaf temperature enabled $M$. cerifera to exploit higher light levels during summer. Young (1992) observed that field-measured net $\mathrm{CO}_{2}$ assimilation rate of M. cerifera peaked around $30^{\circ} \mathrm{C}$, and at $40^{\circ} \mathrm{C}$, net photosynthesis remained within $50 \%$ of maximum values [34]. These results suggest that temperature is a key driver of seasonal changes in photosynthetic performance of $M$. cerifera. Muller et al. (2005) also found that within a given light regime (i.e., that of deciduous forest understory, evergreen forest understory, or a gap in a mixed forest), the photosynthetic apparatus of Aucuba japonica, a temperate understory evergreen shrub, acclimated mainly to changes in temperature and to a lesser extent PAR [22].

There was wide interspecific variation in chlorophyll fluorescence emissions in response to variation in PAR. Steeper slopes in the relationship between PAR and ETR are indicative of greater PE for $M$. cerifera than for $I$. opaca or K. latifolia. Also, M. cerifera displayed similar ETR at intermediate $\left(600-1000 \mu \mathrm{mol} \cdot \mathrm{m}^{-2} \cdot \mathrm{sec}^{-1}\right)$ and high $\left(1200-1600 \mu \mathrm{mol} \cdot \mathrm{m}^{-2} \cdot \mathrm{sec}^{-1}\right)$ light levels throughout the growing season. Net $\mathrm{CO}_{2}$ assimilation rate of $M$. cerifera approached an asymptote at intermediate light levels, also suggesting that photosynthetic performance of $M$. cerifera saturates at intermediate light intensity [34]. The aforementioned results indicate a potential interaction between temperature and PAR. Myrica cerifera may be equally efficient at assimilating carbon at intermediate light intensity as at high light intensity; however, high light $\left(\sim 1600 \mu \mathrm{mol} \cdot \mathrm{m}^{-2} \cdot \mathrm{sec}^{-1}\right)$ and high temperature $\left(\sim 30^{\circ} \mathrm{C}-38^{\circ} \mathrm{C}\right)$ may facilitate increased assimilation rate.

\section{CONCLUSION}

We found that expansive species were more responsive to changes in seasonal leaf temperature. Myrica cerifera and $K$. latifolia, which are both thicket-forming and show enhanced physiological response to rising temperature, are expected to show future range expansion in response to warming climates. Conversely, $I$. opaca, which is slow-growing and shows a low responsiveness to changes in temperature, is likely to occur in a diminished range in the future [15]. While species physiologically similar to I. opaca represent the vast majority of evergreens, studies of expanding species, including some that form thickets, have shown a dramatic increase in range on the order of decades [8,12]. Over the past century, southern Switzerland forest understories have shifted from an indigenous deciduous to an exotic broadleaved shrub layer that appears to benefit from milder winter conditions [61]. From a physiological perspective, our study provides support for the hypothesis that climate change may lead to adjustments in the distribution of evergreens.

The three broadleaf evergreen species of our study demonstrate a wide range of physiological activity. Ilex opaca characteristics and physiology exemplify a typical evergreen species [15]. It has relatively long-lived leaves, slow growth rates [62], and low ETR. Kalmia latifolia also exhibits characteristics and physiology representtative of a typical evergreen species; however, it also displays some traits and physiology that reflect expansive potential. Kalmia latifolia, which has equally longlived leaves as I. opaca, similar seasonal PE and ETR, adjusted leaf angle seasonally, and responded to changes 
in ambient temperature, while $I$. opaca did not. In contrast to I. opaca, M. cerifera departed from characteristics generally associated with evergreenness and is physiologically adapted for a high light environment [34]. It has high growth rates [34,63], PE, ETR across light levels, and leaf nitrogen content [64]. Thus, multiple strategies related to photosynthetic performance and carbon assimilation occur among sympatric evergreen species in deciduous forest understories. Furthermore, our results indicate potential for changes in composition and expansion of the evergreen shrub layer by species that exhibit structural and physiological mechanisms advantageous for future rises in temperature.

\section{ACKNOWLEDGEMENTS}

We would like to thank Steven Brantley, James Deemy, Jared Austin, Ava Hoffman, John Curry, Nancy Shiflett, Travis Nicklow, and Paul Manley for field assistance. Financial support was obtained from a Virginia Commonwealth University Research Assistantship, and Virginia Commonwealth University Rice Center Research grants.This is VCU Rice Center Contribution number 32.

\section{REFERENCES}

[1] Vitousek, P.M. and Walker, L.R. (1989) Biological invasion by Myrica faya in Hawai'i: Plant demography, nitrogen fixation, and ecosystem effects. Ecological Monographs, 59, 247-265. doi:10.2307/1942601

[2] Brothers, T.S. and Spingarn, A. (1992) Forest fragmentation and alien plant invasion of central Indiana oldgrowth forests. Conservation Biology, 6, 91-100. doi:10.1046/j.1523-1739.1992.610091.x

[3] Lavergne, C., Rameau, J.-C. and Figier, J. (1999) The invasive woody weed Ligustrum robustum subsp. walkeri threatens native forests on La Réunion. Biological Invasions, 1, 377-392. doi:10.1023/A:1010001529227

[4] Banasiak, S.E. and Meiners, S.J. (2009) Long term dynamics of Rosa multiflora in a successional system. Biological Invasions, 11, 215-224. doi:10.1007/s10530-008-9226-1

[5] Mitchell, J.D., Lockaby, B.G. and Brantley, E.F. (2011) Influence of Chinese privet (Ligustrum sinense) on decomposition and nutrient availability in riparian forests. Invasive Plant Science and Management, 4, 437-447. doi:10.1614/IPSM-D-11-00020.1

[6] Monk, C.D., McGinty, D.T. and Day Jr., F.P. (1985) The ecological importance of Kalmia latifolia and Rhododendron maximum in the deciduous forest of the southern Appalachians. Bulletin of the Torrey Botanical Club, 112, 187-193. doi:10.2307/29-96415

[7] Beier, C.M., Horton, J.L., Walker, J.F., Clinton, B.D. and Nilsen, E.T. (2005) Carbon limitation leads to suppression of first year oak seedlings beneath evergreen understory shrubs in southern Appalachian hardwood forests. Plant Ecology, 176, 131-142. doi:10.1007/s11258-004-0119-9.
[8] Dobbs, M.M. and Parker, A.J. (2004) Evergreen understory dynamics in Coweeta forest, North Carolina. Physical Geography, 6, 481-498. doi:10.2747/0272-3646.25.6.481

[9] Monk, C.D. and Day, F.P. (1985) Vegetation analysis, primary production and selected nutrient budgets for a southern Appalachian oak forest: A synthesis of IBP studies at Coweeta. Forest Ecology and Management, 10, 87-113. doi:10.1016/0378-1127(85)90015-5

[10] Young, D.R., Shao, G. and Porter, J.H. (1995) Spatial and temporal growth dynamics of barrier island shrub thickets. American Journal of Botany, 82, 628-645. doi: $10.2307 / 2445422$

[11] Kurten, E.L., Snyder, C.P., Iwata, T. and Vitousek, P.M. (2008) Morella cerifera invasion and nitrogen cycling on a lowland Hawaiian lava flow. Biological Invasions, 10, 19-24. doi:10.1007/s10530-007-9101-5

[12] Zinnert, J.C., Shiflett, S.A., Vick, J.K. and Young, D.R. (2011) Woody vegetative cover dynamics in response to recent climate change on an Atlantic coast barrier island: A remote sensing approach. Geocarto International, 26, 595-612. doi:10.1080/10106049.2011.621031

[13] Chapin, F.S. III (1980) The mineral nutrition of wild plants. Annual Review of Ecology and Systematics, 11, 233-260. doi:10.1146/annurev.es.11.110180.001313

[14] Chabot, B.F. and Hicks, D.J. (1982) The ecology of leaf life spans. Annual Review of Ecology and Systematics, 13, 229-259. doi:10.1146/annurev.es.13.110182.001305

[15] Aerts, R. (1995) The advantages of being evergreen. Trends in Ecology and Evolution, 10, 402-407. doi:10.1016/S0169-5347(00)89156-9

[16] Baldocchi, D.D., Ma, S., Rambal, S., Misson, L., Ourcival, J.-M., Limousin, J.-M., Pereira, J. and Papale, D. (2010) On the differential advantages of evergreenness and deciduousness in Mediterranean oak woodlands: A flux perspective. Ecological Applications, 20, 1583-1597. doi:10.1890/08-2047.1

[17] Marty, C., Lamaze, T. and Pornon, A. (2010) Leaf life span optimizes annual biomass production rather than plant photosynthetic capacity in an evergreen shrub. New Phytologist, 87, 407-416. doi:10.1111/j.1469-8137.2010.03290.x

[18] Letts, M.G., Rodríguez-Calcerrada, J., Rolo, V. and Rambal, S. (2012) Long-term physiological and morphological acclimation by the evergreen shrub Buxus simper-virens $\mathrm{L}$. to understory and canopy gap light intensities. Trees, 26, 479-491. doi:10.1007/s00468-011-0609-z

[19] Monk, C.D. (1966) An ecological significance of evergreenness. Ecology, 47, 504-505. doi:10.2307/1932995

[20] Hollinger, D.Y. (1992) Leaf and simulated whole-canopy photosynthesis in two co-occurring tree species. Ecology, 73, 1-14. doi: $10.2307 / 1938716$

[21] Givnish, T.J. (2002) Adaptive significance of evergreen vs. deciduous leaves: Solving the triple paradox. Silva Fennica, 36, 703-743.

[22] Muller, O., Hikosaka, K. and Hirose, T. (2005) Seasonal changes in light and temperature affect the balance between light harvesting and light utilization components of 
photosynthesis in an evergreen understory shrub. Oecologia, 143, 501-508. doi:10.1007/s00442-005-0024-5

[23] Wang, X., Arora, R., Horner, H.T. and Krebs, S.L. (2008) Structural adaptations in overwintering leaves of thermonastic and nonthermonastic Rhododendron species. Journal of the American Society for Horticultural Science, 133, 768-776.

[24] Muller, O., Hirose, T., Werger, M.J.A. and Hikosaka, K. (2011) Optimal use of leaf nitrogen explains seasonal changes in leaf nitrogen content of an understorey evergreen shrub. Annals of Botany, 108, 529-536. doi:10.1093/aob/mcr167

[25] Chazdon, R.L. (1986) Light variation and carbon gain in rain forest understorey palms. Journal of Ecology, 74, 995-1012. doi: $10.2307 / 2260229$

[26] Chazdon, R.L. and Pearcy, R.W. (1991) The importance of sunflecks for forest understory plants. Bioscience, 41, 760-766. doi: $10.2307 / 1311725$

[27] Neufeld, H.S. and Young, D.R. (2003) Ecophysiology of the herbaceous layer in temperate deciduous forest. In: Gilliam, F.S. and Roberts, M.R., Eds., The Herbaceous Layer in Forest in Eastern North America, Oxford University Press, Oxford, 38-90.

[28] Roberts, S.W., Knoerr, K.R. and Strain, B.R. (1979) Comparative field water relations of four co-occurring forest tree species. Canadian Journal of Botany, 57, 1876-1882. doi:10.1139/b79-237

[29] Young, D.R. (1985) Crown architecture, light interception, and stomatal conductance patterns for sympatric deciduous and evergreen species in a forest understory. Canadian Journal of Botany, 63, 2425-2429. doi:10.1139/b85-346

[30] Krinard, R.M. (1973) American holly: An American wood. United States Department of Agriculture Forest Service. FS-242.

[31] Valladares, F., Arrieta, S., Aranda, I., Lorenzo, D., Sánchez-Gómez, D., Tena, D., Suárez, F. and Pardos, J.A. (2005) Shade tolerance, photoinhibition sensitivity and phenotypic plasticity of Ilex aquilifolium in continental Mediterranean sites. Tree Physiology, 25, 1041-1052. doi:10.1093/treephys/25.8.1041

[32] Reich, P.B., Walters, M.B., Ellsworth, D.S., Vose, J.M., Volin, J.C., Gresham, C. and Bowman, W.D. (1998) Relationships of leaf dark respiration to leaf nitrogen, specific leaf area and leaf life-span: A test across biomes and functional groups. Oecologia, 114, 471-482. doi: $10.1007 / \mathrm{s} 004420050471$

[33] Hughes, N.M. and Smith, W.K. (2007) Seasonal photosynthesis and anthocyanin production in ten broadleaf evergreen species. Functional Plant Biology, 34, 10721079. doi:10.1071/FP07205

[34] Young, D.R. (1992) Photosynthetic characteristics and potential moisture stress for the actinorhizal shrub, Myrica cerifera (Myricaceae), on a Virginia barrier island. American Journal of Botany, 79, 2-7. doi: $10.2307 / 2445189$

[35] Brantley, S.T. and Young, D.R. (2010) Linking light attenuation, sunflecks and canopy architecture in mesic shrub thicket. Plant Ecology, 206, 225-326. doi:10.1007/s11258-009-9637-9

[36] Lichtenthaler, H.K. (1987) Chlorophylls and carotenoids: Pigments of photosynthetic biomembranes. Methods in Enzymology, 148,350-382. doi:10.1016/0076-6879(87)48036-1

[37] Schreiber, U., Bilger, W. and Neubauer, C. (1994) Chlorophyll fluorescence as a non-intrusive indicator for rapid assessment of in vivo photosynthesis. In: Schulze, E.D. and Caldwell, M.M., Eds., Ecophysiology of Photosynthesis, Ecological studies, Springer, Berlin, 49-70.

[38] Jones, T.J., Luton, C.D., Santiago, L.S. and Goldstein, G. (2010) Hydraulic constraints on photosynthesis in subtropical evergreen broad leaf forest and pine woodland trees of the Florida Everglades. Trees, 24, 471-478. doi:10.1007/s00468-010-0415-Z

[39] Schreiber, U., Neubauer, C. and Klughammer, C. (1988) New ways of assessing photosynthetic activity with a pulse modulation fluorometer. In: Lichtenthaler, H.K., Ed., Applications of Chlorophyll Fluorescence, Kluwer Academic Publishing, Dordrecht, 63-69.

[40] Lovelock, C.E., Osmond, C.B. and Jebb, M. (1994) Photoinhibition and recovery in tropical plant species: Response to disturbance. Oecologia, 97, 297-307.

[41] Genty, B., Briantais, J.M. and Baker, N.R. (1989) The relationship between the quantum yield of photosynthetic electron transport and quenching of chlorophyll fluorescence. Biochimica et Biophysica Acta, 990, 87-92. doi:10.1016/S0304-4165(89)80016-9

[42] Demmig-Adams, B., Maguas, C., Adams, W.W. III, Meyer, A., Kilian, E. and Lange, O.L. (1990) Effect of high light on the efficiency of photochemical energy conversion in a variety of lichen species with green and bluegreen phycobionts. Planta, 180, 400-409. doi:10.1007/BF01160396

[43] Andrews, J.R., Fryer, M.J. and Baker, N.R. (1995) Characterization of chilling effects on photosynthetic performance of maize crops during early season growth using chlorophyll fluorescence. Journal of Experimental Botany, 46, 1195-1203. doi:10.1093/jxb/46.9.1195

[44] Stemke, J.A. and Santiago, L.S. (2011) Consequences of light absorptance in calculating electron transport rate of desert and succulent plants. Photosynthetica, 49, 195-200. doi:10.1007/s11099-011-0026-y

[45] Zinnert, J.C., Via, S.M. and Young, D.R. (2013) Distinguishing natural from anthropogenic stress in plants: Physiology, fluorescence and hyperspectral reflectance. Plant and Soil, 366, 133-141. doi:10.1007/s11104-012-1414-1

[46] Naumann, J.C., Young, D.R. and Anderson, J.E. (2007) Linking leaf chlorophyll fluorescence properties to physiological responses for stress detection in coastal plant species. Physiologia Plantarum, 131, 422-433. doi:10.1111/j.1399-3054.2007.00973.x

[47] Flores-Moya, A., Hanelt, D., Figueroa, F.-L., Altamirano, M., Viñegla, B. and Salles, S. (1999) Involvement of solar UV-B radiation in recovery of inhibited photosynthesis in the brown alga Dictyota dichotoma (Hudson) Lamouroux. Journal of Photochemistry and Photobiology B: 
Biology, 49, 129-135. doi:10.1016/S1011-1344(99)00046-9

[48] Campbell, G.S. (1990) Derivation of an angle density function for canopies with ellipsoidal leaf angle distributions. Agricultural and Forest Meteorology, 49, 173-176. doi:10.1016/0168-1923(90)90030-A

[49] Sands, P.J. (1995) Modeling canopy production 1: Optimal distribution of photosynthetic resources. Australian Journal of Plant Physiology, 22, 593-601. doi:10.1071/PP9950593

[50] Drouet, J.L. and Moulia, B. (1997) Spatial re-orientation of maize leaves affected by initial plant orientation and density. Agricultural and Forest Meteorology, 88, 85-100. doi:10.1016/S0168-1923(97)00047-6

[51] Falster, D.S. and Westoby, M. (2003) Leaf size and angle vary widely across species: What consequences for light interception? New Phytologist, 158, 509-525. doi:10.1046/j.1469-8137.2003.00765.x

[52] Teh, C.B.S., Simmonds, L.P. and Wheeler, T.R. (2000) An equation for irregular distributions of leaf azimuth density. Agricultural and Forest Meteorology, 102, 223-234. doi:10.1016/S0168-1923(00)00132-5

[53] Whitney, G.G. (1976) The bifurcation ratio as an indicator of adaptive strategy in woody plant species. Bulletin of the Torrey Botanical Club, 103, 67-72. doi: $10.2307 / 2484833$

[54] Kempf, J.S. and Pickett, S.T.A. (1981) The role of branch length and angle in branching pattern of forest shrubs along a successional gradient. New Phytologist, 88, 111116. doi:10.1111/j.1469-8137.1981.tb04574.x

[55] Brantley, S.T. and Young, D.R. (2009) Contribution of sunflecks is minimal in expanding shrub thickets compared to temperate forest. Ecology, 90, 1021-1029. doi: $10.1890 / 08-0725.1$
[56] Steingraeber, D.A., Kascht, L.J. and Franck, D.H. (1979) Variation in shoot morphology and bifurcation ratio in sugar maple (Acer saccharum) saplings. American Journal of Botany, 66, 441-445. doi:10.2307/2442397

[57] Demmig-Adams, B., Gilmore, A.M. and Adams, W.W. III. (1996) In vivo functions of carotenoids in higher plants. The FASEB Journal, 10, 403-412.

[58] Boardman, N.K. (1977) Comparative photosynthesis of sun and shade plants. Annual Review of Plant Physiology, 28, 355-377.doi:10.1146/annurev.pp.28.060177.002035

[59] Martin, C.E. and Warner, D.A. (1984) The effects of desiccation on concentrations and $\mathrm{a} / \mathrm{b}$ ratios of chlorophyll in Leucobryum glaucum and Thuidium delicatulum. New Phytologist, 96, 545-550. doi:10.1111/j.1469-8137.1984.tb03588.x

[60] Dale, M.P. and Causton, D.R. (1992) Use of chlorophyll $a / b$ ratio as a bioassay for the light environment of a plant. Functional Ecology, 6, 190-196. doi:10.2307/2389754

[61] Walther, G.R. (2000) Climatic forcing on the dispersal of exotic species. Phytocoenologia, 30, 409-430.

[62] Potter, D.A. and Kimmerer, T.W. (1986) Seasonal allocation of defense investment in Ilex opaca Aiton and constraints on a specialist leafminer. Oecologia, 69, 217- 224. doi:10.1007/BF00377625

[63] Young, D.R. (2007) Estimating aboveground net primary production in shrub-dominated ecosystems. In: Fahey, T.J. and Knapp, A.K., Eds., Principles and standards for measuring primary production, Oxford University Press, NewYork, 49-68. doi:10.1093/acprof:oso/9780195168662.003.0004

[64] Vick, J.K. (2011) Woody encroachment mechanisms of a symbiotic N-fixing shrub: Ecophysiology, facilitation, and resource use efficiency. $\mathrm{PhD}$ dissertation, Virginia Commonwealth University, Richmond. 